\title{
Die-out of Manilkara hexandra from Bundala National Park, Sri Lanka: Causes and Some Possible Underlying Mechanisms
}

\author{
R.M.U.K. Gunarathne $e^{1,2}$ and G.A.D. Perera ${ }^{1,2^{*}}$ \\ ${ }^{1}$ Postgraduate Institute of Science, University of Peradeniya, Peradeniya, Sri Lanka \\ ${ }^{2}$ Department of Botany, University of Peradeniya, Peradeniya, Sri Lanka
}

Date Received: 08-12-2013 Date Accepted: 31-03-2014

\begin{abstract}
Bundala National Park (BNP) is a biologically diverse wetland habitat where a sizable area of Tropical Semi-deciduous (TSD) forests of Sri Lanka exists. Manilkara hexandra is the only dominant canopy tree species in these forests. However, the species appears to be dying out from BNP. With the aim of revealing the causes and possible underlying reasons for the die-out of the species, the population size, spatial distribution, natural regeneration and the healthiness of individuals of $M$. hexandra in BNP were examined in twenty five $50 \times 50 \mathrm{~m}^{2}$ plots in three-belt transects which were established across different forest categories in BNP. The major alien exotic plants in these plots were also enumerated. Results revealed that the tree die-back and poor natural regeneration were among the major causes for the die-out of $M$. hexandra from BNP, which had altered the population structure and distribution of the species over space. Live individuals of the species were absent in some degraded sites especially those invaded by Prosopis juliflora. Presence of over-mature cohorts, occurrence of tree cankers and presence of the aggressive invader, $P$. juliflora appear to affect the die-back of $M$. hexandra. This study provides a clue that there is a possibility of dying-back of the remaining healthy trees of $M$. hexandra in TSD forests of BNP in the near future, unless the threats imposed upon $M$. hexandra are uplifted through strategic management activities.
\end{abstract}

Key words: invasion, natural regeneration, population structure, tree cankers, tropical semideciduous forest

\section{Introduction}

Dying out of species is recorded as a major threat to the tropical biodiversity and has been reported from many tropical ecosystems in the world (Whitmore \& Sayer, 1992). Habitat alterations and loss, over-harvesting, species and disease introduction, pollution and climate change have been cited as major direct or proximate causes which lead to the loss of plant and animal species, possibly to their extinction. Among these, habitat alteration is clearly a predominant cause and is a problem that operates mainly at the local level (Wood et al., 2000). The die-back of populations of tree species is increasingly being heard as a way of habitat alterations and consequent possible loss of given species. However, the underlying causes for forest or tree die-back may vary with the region or the site.

Air pollution has often been reported as the cause for forest die-back in many areas of the temperate regions of the world (Smith, 1981; Hinrichsen, 1986, 1987; Vries et al., 2000).

*Correspondence: anomap@pdn.ac.lk

Tel: +94812394520

ISSN 2235-9370 Print/ISSN 2235-9362 Online (C University of Sri Jayewardenepura 
The acid rain produced due to air pollution is often cited as a major cause for the forest dieback (Vogelmann et al., 1985; Pitelka and Raynal, 1989; Kandler \& Innes, 1995). For instance, the atmospheric sulfur dioxide concentration was very high in the Ore Mountains of northern Bavaria, Germany where the forest decline was reported to be very severe (Prinz, 1985). Acid rains may enhance soil acidification and subsequent aluminum toxicity in plants (Ulrich, 1983). However, extreme climatic conditions (Auclair, 1993) especially temperature (frost formation) and drought stresses are also reported to cause forest declines (Fensham \& Holman, 1999; Vries et al., 2000) or to contribute to the synchrony of the declines (Prinz, 1985; Blank, 1986). In addition, Redmond (1955) has reported that the death of yellow birch (Betula sp.) trees may be due to the growth of Cylindroporium sp. in the soil at elevated soil temperatures and the subsequent suppression of mycorrhizal fungi in the rhizosphere.

On the other hand, forest die-back in the tropical regions of the world often appears as occurring due to extreme climatic conditions, especially due to extreme drought conditions (Auclair, 1993) or due to the climate change (Mueller-Dombios, 1980). For instance, prolonged drought is reported as a major underlying cause for forest die-back in both Mudumalai dry forests in Southern India (Suresh et al., 2010) and in savanna forests in Queensland, Australia (Rice et al., 2004), while the El Niño drought events are reported to cause forest die-back in tropical rain forests of North of Manaus, Brazil (Laurance et al., 2001) and in North East Australia (Rice et al., 2004).

Changes in soil chemical composition (Ulrich et al., 1980) or soil nutrient imbalances (Mader \& Thompson, 1969; Gerrish et al., 1988; Schulze, 1989; Turner and Lambert, 2005; Mueller-Dombois, 1990) have also been identified as creating a stress situation in plants ultimately resulting in plant death. For instance, it is reported that the die-back of Metrosideros polymorpha dominant rain forests has been due to soil nutrient stresses (Jacobi, 1983; Mueller-Dombios, 1990). Plants weakened due to soil nutrient imbalances would frequently be attacked by secondary agents such as insects (Papp et al., 1979; Johnson \& McLaughlin, 1986; Bauce \& Allen, 1992) and pathogens (Hibber, 1964; Papp et al., 1979; Carey et al., 1984; Mueller-Dombois, 1986; Bauce \& Allen, 1992; Sankaran et al., 2005). Similarly, long-term accumulation of Nitrogen in the soils of Eucalypt forests in Australia has resulted in increased amino acid contents in Eucalypt leaves and the subsequent increased herbivory (Turner \& Lambert, 2005). Although the die-back of $M$. hexandra in Bundala National Park (BNP), Sri Lanka has been reported (Bambaradeniya et al., 2002), the causes and underlying mechanisms for this tree die-back have not yet been revealed.

$M$. hexandra is a dominant canopy tree species in dry forests of Sri Lanka but the natural regeneration of the species is recorded to be very poor (Holmes, 1956). The species is reckoned to be the sole dominant canopy species in tropical semi-deciduous forests at BNP, where it is severely dying-out (Perera, 2012). Dead trees of the species are seen especially closer to lagoons and inland water bodies. The alien exotic, Prosopis juliflora had invaded such affected areas forming $P$. juliflora dominant degraded forest stands. However, the vegetative and reproductive phenological events in the remaining live individuals of $M$. hexandra in the area have not been affected and mass fruiting takes place in every 3-4 years (Gunarathne \& Perera, 2014).

$M$. hexandra is the only species affected in BNP and this implies that the causes for tree die-back may be rather species specific. It is vital to investigate carefully and methodically the reasons behind the die-back of this sole dominant canopy species in order to prepare guidelines for conservation of the species and for the management of the affected areas. The study of the population distribution and the magnitude and nature of die-back disturbance is therefore of prime importance in both planning further research and managing the area. Therefore, a detailed survey of the population of $M$. hexandra in BNP was conducted 
with the aim of revealing the causes and possible underlying reasons behind the die-out of the population of $M$. hexandra in BNP by assessing the spatial variation in the population structure (based on density, dbh and height), the natural regeneration of the species and the tree healthiness.

\section{Materials and Methods}

\subsection{Study area and the climate}

The Bundala National Park lies along the south coast of Hambantota District in the low country dry zone of Sri Lanka $\left(6^{0} 08^{\prime}-6^{0} 14^{\prime} \mathrm{N}, 81^{0} 08^{\prime}-81^{0} 18^{\prime} \mathrm{E}\right)$ (Fig. 1). The park area extends over an area of 3,698.01 ha (Gazette notice $28^{\text {th }}$ July 2004). Four shallow brackish water lagoons are situated in the park (from West to the East), namely, Koholankala, Malala, Embilikala and Bundala.

In general, a hot and dry climate prevails in the area with an average annual rainfall of $1059 \mathrm{~mm}$ (Gunarathne \& Perera, 2014). The rainfall pattern is related to the monsoon periods and the area receives the highest rainfall around November during the North-East monsoon period. There are two distinct dry seasons per year; a short dry season from February to March and a long dry season from May to August or September. The average annual temperature in the study area during the period from 1995 to 2008 was $27.8{ }^{0} \mathrm{C}$ with the mean maximum and mean minimum monthly temperatures of $35.7{ }^{\circ} \mathrm{C}$ and $22.9{ }^{\circ} \mathrm{C}$, respectively. The average monthly relative humidity of the area varies around $70-80 \%$ (Gunarathne \& Perera, 2014).

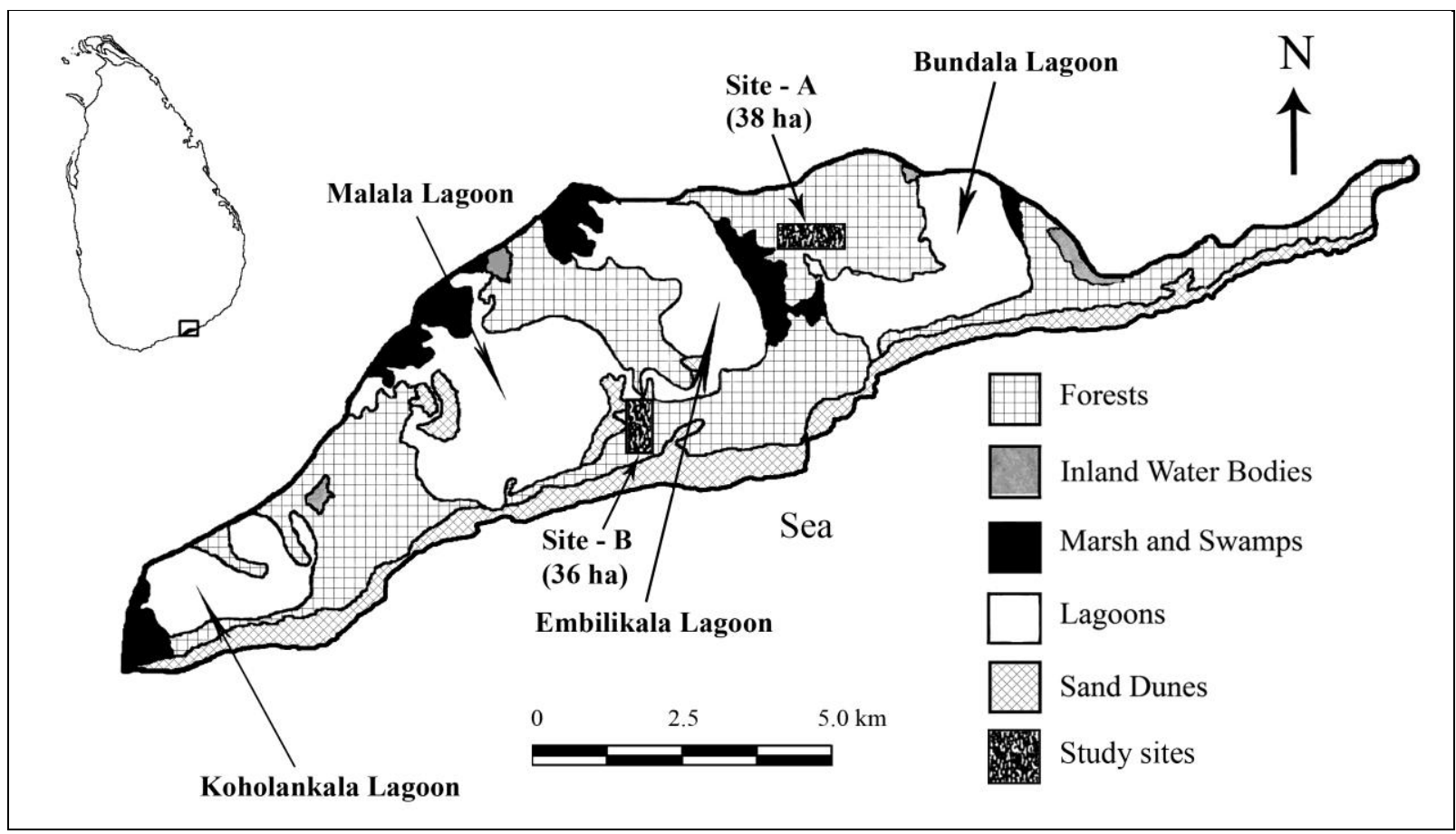

Fig. 1: Bundala National Park depicting the locations of the study sites.

\section{Vegetation}

Tropical Semi-Deciduous (TSD) forests in which the forest canopy comprised $M$. hexandra alone are the typical native forest vegetation in BNP (Perera, 2012). However, the park area appears to be disturbed by different ways from time to time. Some parts, especially 
the northern and central parts of the Park (e.g. Site A in Fig. 1) have been disturbed in the 1970s due to shifting cultivation and by selective logging (personal communication with the park officers and local villagers) and other continuous animal and anthropogenic activities. All these ultimately resulted in the formation of Scrub Jungles (SJ) with scattered remnant $M$. hexandra trees and maintained these at a plagioclimax state (Perera, 2012).

Four forest vegetation types can be visually identified in the southern part of BNP (in Site B) by the differences in their vegetation structure and physiognomy. Of these, TSD forests occur as small patches but the forests surrounding these are degraded with many dying-back trees of $M$. hehandra. Such Degraded Tropical Semi-Deciduous (DTSD) forests are rather open with more light demanding understorey species such as Azima tetracantha and Ziziphus oenoplia though they are as tall as TSD forests. Degraded Shrublands (DS) occur adjacent to DTSD forests and are dominated by species like A. tetracantha, Cassia auriculata, Dichrostachys cinerea and Flueggea leucopyrus but, $M$. hexandra is either very rare or absent in these. Prosopis juliflora dominant (PD) forest stands which occur closer to lagoons and inland water bodies and contain very few plant species. Of these, A. tetracantha, Opuntia dillenii and Salvadora persica are some commonly occurring species in these forest stands.

\section{Selection of Study sites}

With the aid of aerial photographs of the area taken in 1957, 1971 and 1981 (Survey Department of Sri Lanka) and by a reconnaissance survey, two study sites were selected for the study. SJs with scattered $M$. hexandra that maintained as a plagioclimax vegetation at the northern part of the Bundala lagoon (Site A) extending over 38 ha and relatively undisturbed TSD forests and adjacent degraded forest patches at the southern part of the park (Site B) extending over an area of 36 ha (Fig. 1) constitute these study sites.

\section{Establishment of belt transects and enumeration of individuals of $M$. hexandra}

Three $50 \mathrm{~m}$ wide belt transects were established at randomly chosen points in the two selected study sites. As the SJ in the site A appeared more or less homogenous, only one $50 \mathrm{~m}$ wide belt transect was established at the site on a randomly chosen location along the EastWest direction. Two transects were established at site $\mathrm{B}$, one across a vegetation gradient from PD forest stands to Relatively Undisturbed TSD forests along the North-South direction, passing through DSs and DTSD forests while the other along the East-West direction crossing at a randomly selected point perpendicular to the first belt transect.

All the established belt transects in the two sites were sub-divided into $50 \times 50 \mathrm{~m}^{2}$ experimental plots and thus, 2 experimental plots were located in the PDF stand, 5 plots in DSs, 4 plots in HDTS forest, 6 plots in TSD forest in site B while 8 plots were located in SJs in site A. Individuals of $M$. hexandra in each experimental plot were enumerated and tagged. The height of individuals which were taller than $4 \mathrm{~m}$ was measured using a clinometer (Suunto PM-5), while the individuals shorter than $4 \mathrm{~m}$ were measured using a calibrated pole. Tree diameter at breast height (dbh) was measured using a dbh tape (Lufkin ${ }^{\circledR}$ Executive Thinline, W606PM) if the dbh of individuals was $>2 \mathrm{~cm}$. The abundance of dreadful invader, $P$. juliflora was estimated in circular plots of $15 \mathrm{~m}$ radius which established around each mature individual ( $\mathrm{dbh}>2 \mathrm{~cm}$ ) of $M$. hexandra, while the frequency of occurrence of Opuntia dillenii in these circular plots was recorded. In PDF stands and in DSs where M. hexandra trees were absent, 3-4 circular plots were established at randomly chosen locations and the abundance of $P$. juliflora and the presence/absence of $O$. dillenii in these were recorded. Healthiness of individuals of $M$. hexandra present in the study site was observed and recorded using a 5 point scale, modified from McLaughlin et al. (1992) (Table 1). 
Table 1: Five point tree die-back scale used to classify the healthiness of M. hexandra trees.

\begin{tabular}{lcc}
\hline Health Category & $\begin{array}{c}\text { Symbol used to } \\
\text { denote the health } \\
\text { category }\end{array}$ & Scale \\
\hline Healthy & H & $\leq 15 \%$ crown die-back or defoliation \\
Trace Level Die-back & TLD & $16-25 \%$ crown die-back or defoliation \\
Low Level Die-back & LLD & $26-50 \%$ crown die-back or defoliation \\
Moderate Level Die-back & MLD & $51-75 \%$ crown die-back or defoliation \\
Severe Die-back & SD & $\geq 76 \%$ crown die-back or defoliation \\
\hline
\end{tabular}

\section{Results}

\subsection{Structure of the population of M. hexandra in the study area}

Results revealed that the density of the live individuals of $M$. hexandra significantly varied among the different forest categories studied (Table 2; Kruskal-Wallies Test: $p=0.002$ ). The density of $M$. hexandra trees in SJs at the site A is somewhat different from that in site B as the site A contains a fewer number of $M$. hexandra trees with a fewer number of dead stumps.

Table 2: Density of $M$. hexandra in different forest vegetations of BNP (Individuals of all sizeclasses were considered).

\begin{tabular}{|c|c|c|c|}
\hline \multirow[t]{2}{*}{ Site } & \multirow[t]{2}{*}{ Forest category } & \multicolumn{2}{|c|}{$\begin{array}{c}\text { Density of individuals of } \\
M . \text { hexandra }\left(\mathrm{ha}^{-1}\right)\end{array}$} \\
\hline & & Live & Dead \\
\hline A & Scrub jungles & 14 & 1 \\
\hline B & $\begin{array}{l}\text { Prosopis dominant forest } \\
\text { stands }\end{array}$ & 0 & 28 \\
\hline B & Degraded shrublands & 1 & 25 \\
\hline B & $\begin{array}{l}\text { Degraded tropical semi- } \\
\text { deciduous forests }\end{array}$ & 21 & 39 \\
\hline B & $\begin{array}{l}\text { Relatively undisturbed tropical } \\
\text { semi-deciduous forests }\end{array}$ & 58 & 7 \\
\hline
\end{tabular}

The highest density of $M$. hexandra was recorded in TSD forests in the site $\mathrm{B}$. There were many dead trees of $M$. hexandra in PD forest stands, DS and in DTSD forests. Notably, there was not a single live $M$. hexandra tree in PD forest stands while a few occasionally scattered $M$. hexandra trees were found in DS located adjacent to PD forest stands, despite that there were many dead and fallen trees of $M$. hexandra in these two forest stands (Table 2). Fig. 2 depicts the dbh distribution of $M$. hexandra in different forest stands in BNP. The majority of live individuals (87\%) of $M$. hexandra in both study sites (A and B) was large and had a dbh above $22 \mathrm{~cm}$ (Fig. 2). Fig. 2 further shows that the dbh distribution of $M$. hexandra in all sub-populations was highly distorted due to the absence of smaller individuals of the species. For instance, the density of individuals having a dbh $<2.0 \mathrm{~cm}$ was 2 per ha while those having a dbh within the range $2.1-22.0 \mathrm{~cm}$ was 3 per ha. In contrast, the density of individuals of which the dbh was $>22 \mathrm{~cm}$ was as high as 27 per ha. The height-class distribution of the species showed that a majority of the individuals have reached the canopy and were taller than $7 \mathrm{~m}$ (Fig. 3). The density of individuals shorter than $2 \mathrm{~m}$ varied from 1-3 per ha (Fig. 3). 

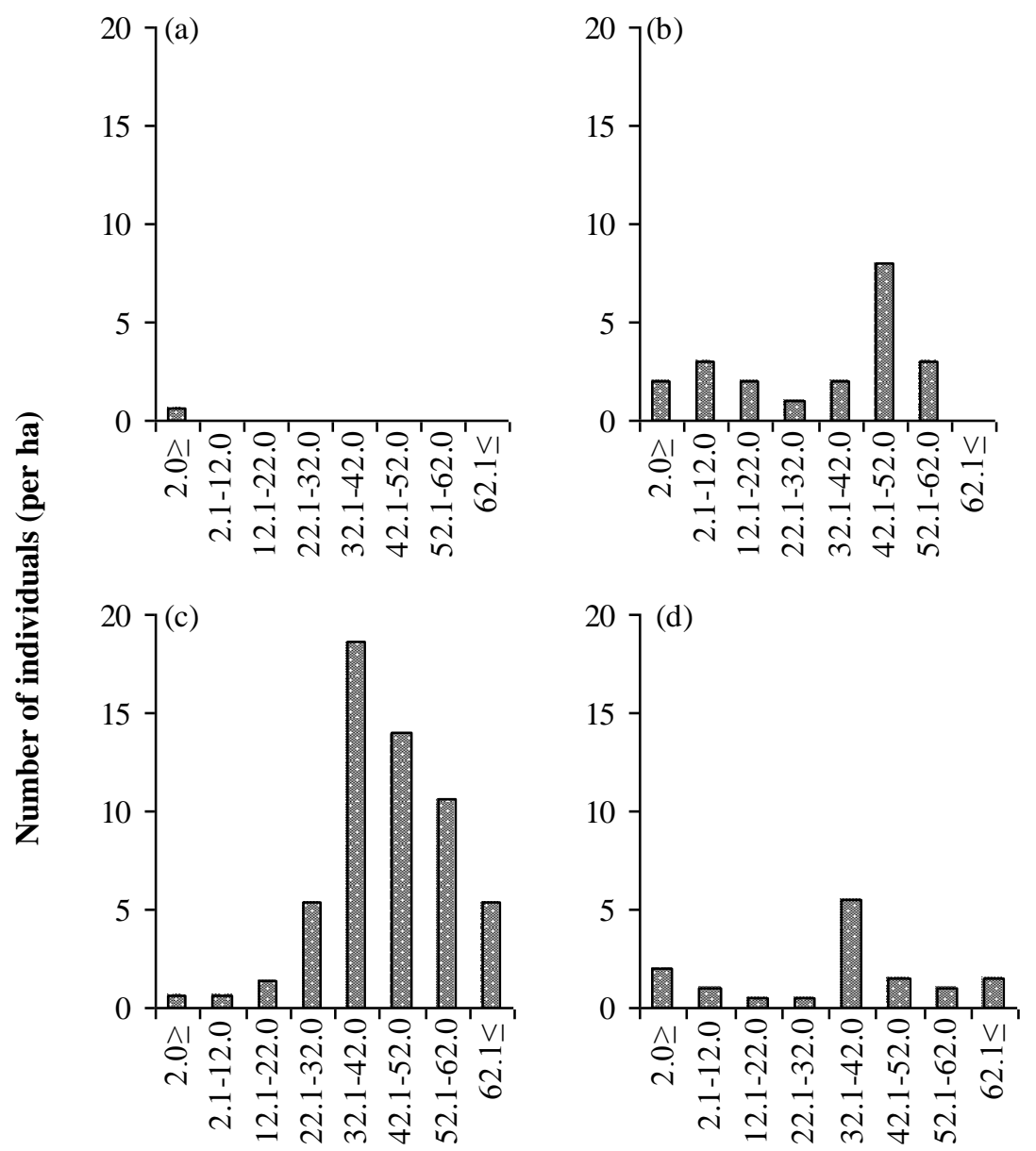

Diameter-class (cm)

Fig. 2. Diameter-class distribution of live individuals of M. hexandra in (a) DS, (b) DTSD forests (c) TSD forests and (d) SJ forests (PD forest stands are not included here as these forests do not contain any live individuals of $M$. hexandra).

\subsection{Healthiness and tree die-back of $M$. hexandra in different forest categories}

It is evident from Fig. 4 that both saplings and mature individuals can be affected by the tree die-back. However, seedlings $(<2 \mathrm{~cm}$ dbh) with die-back symptoms were not found in the study area. The experimental plots established at DSs contained only one seedling of $M$. hexandra but no individuals of the species with $\mathrm{dbh}>2 \mathrm{~cm}$ were not found from this forest type. Moreover, a lower fraction of individuals in relatively undisturbed TSD forest showed dying-back symptoms compared to DTSD and SJ forests.

Fig. 5 shows the occurrence of die-back symptoms in $M$. hexandra (where the dbh $>2$ $\mathrm{cm})$ in different forest categories as per Table 1 . About a half $(50 \%)$ of the individuals of $M$. hexandra in relatively undisturbed TSD forest stands was in a healthy condition but the remainder showed die-back symptoms to different degrees. Majority of these unhealthy individuals exhibited 16-50\% crown die-back or defoliation (i.e., exhibiting die-back symptoms at trace or low levels). In contrast, most of the live trees (nearly 90\%) in DTSD forests showed tree die-back symptoms to various degrees and only around $10 \%$ of individuals of $M$. hexandra in DTSD forests were healthy by the time of sampling. Moreover, no live $M$. hexandra tree with dbh $>2 \mathrm{~cm}$ was found in both DS and PD forest stands. 

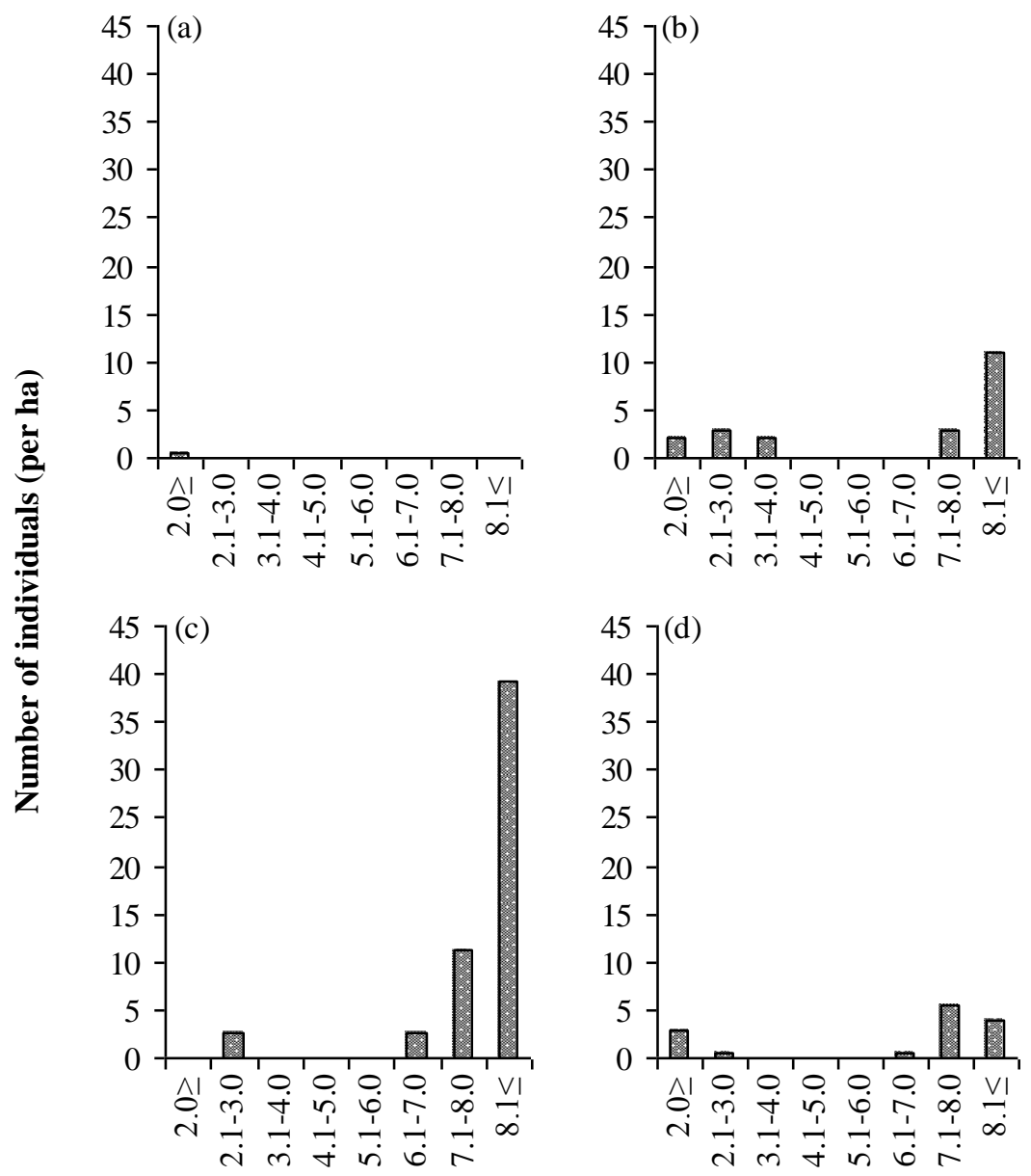

Height-class (m)

Fig. 3: Height-class distribution of live individuals of M. hexandra in (a) DS, (b) DTSD forests (c) TSD forests and (d) SJ forests (PD forest stands are not included as these forests do not contain any live $M$. hexandra trees).

The SJ in site A is somewhat different from the rest of the forest stands and the majority of individuals (nearly 90\%) in it was alive and healthy. Those showing die-back symptoms also exhibited crown die-back or defoliation to trace or low levels.

\subsection{Threats to the population of $M$. hexandra in the study area}

As given in Table 3, the percentage occurrence of dead and dying back trees in examined vegetation types was significantly different ( $p=0.001$ and $p=0.002$, respectively) and there were no live trees of the species where $\mathrm{dbh}>2 \mathrm{~cm}$ in both PD forest stands and in DSs. Similarly, the density of the aggressive invader, $P$. juliflora varied significantly among different forest types $(p=0.001)$ and a weak correlation exists between the density of $P$. juliflora trees the dead and dying-back $M$. hexandra trees (Pearsons Correlation test, $\mathrm{R}^{2}$ $=0.343$ ). The density of $P$. juliflora was higher in PD forest stands and DS but lower in DTSD forests. Although no $P$. juliflora trees were recorded within experimental plots established in SJ, several individuals of this species were found to be growing adjacent to the established experimental plots. 
(a)

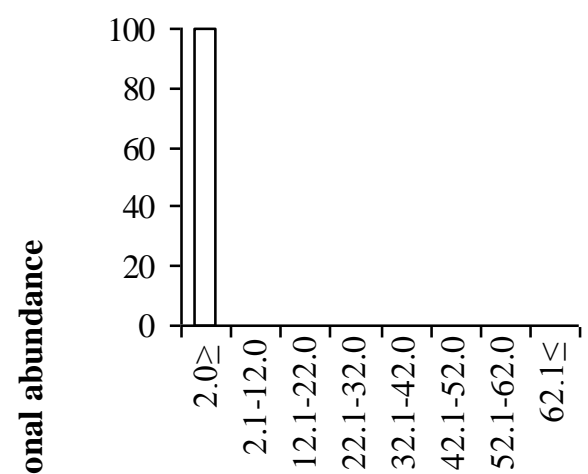

(c)

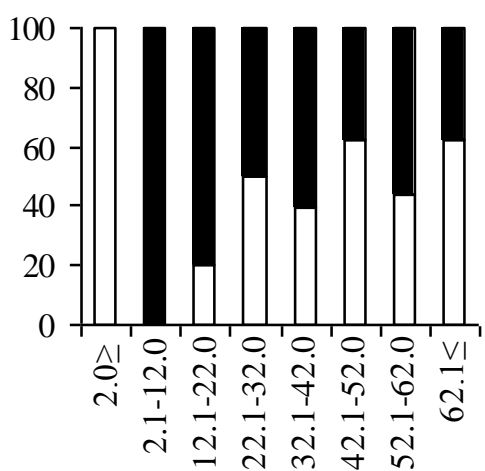

(b)

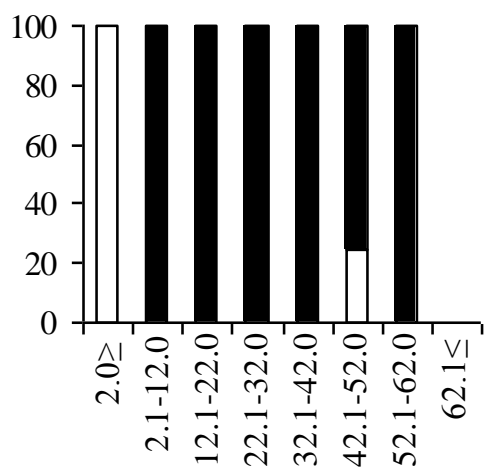

(d)

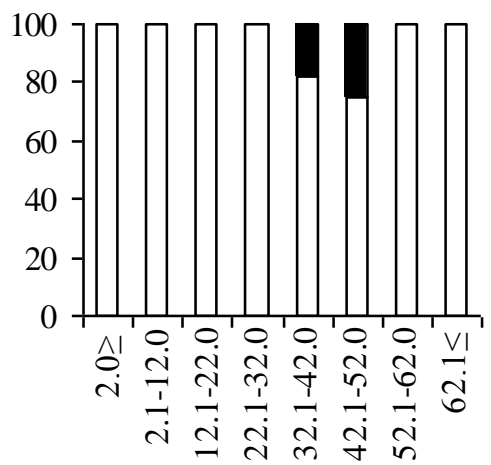

Diameter-class (cm)

Healthy

Dying back

Fig. 4: Proportional abundance of healthy and dying-back individuals of M. hexandra in relation to the respective tree diameter size classes in (a) DS, (b) DTSD forests (c) TSD forests and (d) SJ forests in BNP.

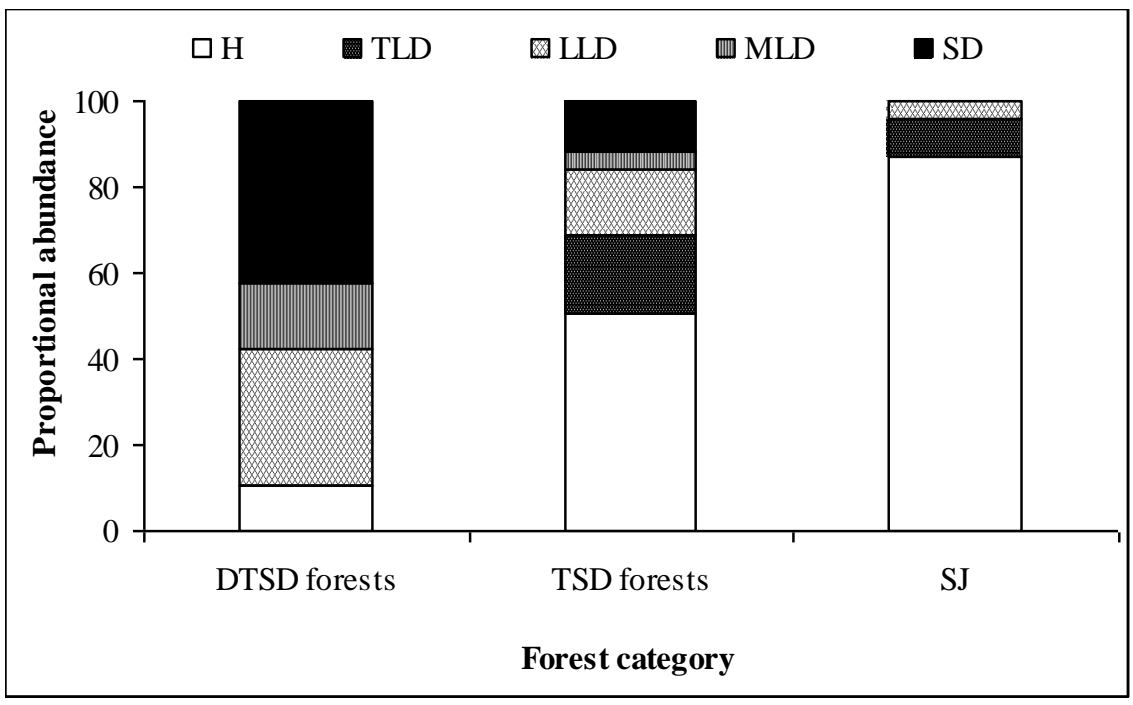

Fig. 5: Proportional abundance of individuals of $M$. hexandra whose $d b h \geq 2 \mathrm{~cm}$ at examined different forest categories in BNP under healthiness/die-back symptom categories as given in Table 1. 
Opuntia dillenii is another common invasive plant in BNP and the frequency of occurrence of $O$. dillenii varied significantly among different forest types $(p=0.003)$. The species thrives luxuriantly in more disturbed forest vegetations. Thus, the species is very common in DSs, PD forest stands and in SJ forests (Table 3). The species was not found in relatively undisturbed TSD forest plots with an exception at the edges of TSD forests or by the sides of roads.

Visually observable common diseases of $M$. hexandra included the Ganoderma infection and canker disease. Fruiting bodies of Ganoderma sp. were entirely found on dead individuals of $M$. hexandra but not on live trees (Table 3). There were many dead or fallen trees in the DS and PD forest stands and these contained many fruiting bodies of Ganoderma sp.

In contrast, tree canker disease appeared as a major threat to the individuals of $M$. hexandra in the study area and more than $80 \%$ of individuals in BNP bear tree cankers (Table $3)$. These were found to be occurred on any large individuals of $M$. hexandra irrespective of the forest type $(p=0.927)$. Cankers were present on the stem, branches or at the base of the trunks of $M$. hexandra trees but those on branches and stems were more prominently found in all forest types.

Table 3: Analysis of major threats to M. hexandra in BNP.

\begin{tabular}{llllll}
\hline Type of threats & \multicolumn{5}{c}{ Forest type } \\
\cline { 2 - 6 } & $\begin{array}{l}\text { PD forest } \\
\text { stand }\end{array}$ & DS & $\begin{array}{l}\text { DTSD } \\
\text { forests }\end{array}$ & $\begin{array}{l}\text { TSD } \\
\text { forests }\end{array}$ & SJ \\
\hline \% of dead $M$. hexandra trees & 100 & $98( \pm 2)$ & $60( \pm 15)$ & $8( \pm 3)$ & $7( \pm 7)$ \\
\hline $\begin{array}{l}\text { \% occurrence of dying-back trees of } \\
M . \text { hexandra }\end{array}$ & 0 & 0 & $93( \pm 7)$ & $50( \pm 11)$ & $13( \pm 11)$ \\
\hline Density of $P$. juliflora (per ha) & $132( \pm 30)$ & $134( \pm 27)$ & $19( \pm 7)$ & $1( \pm 1)$ & 0 \\
\hline $\begin{array}{l}\text { Frequency of occurrence of } \\
\text { O. dillenii }(\%)\end{array}$ & $5( \pm 5)$ & $54( \pm 16)$ & $11( \pm 5)$ & $6( \pm 6)$ & $94( \pm 4)$ \\
\hline $\begin{array}{l}\text { Live } M \text {. hexandra } \text { trees with } \\
\text { Ganoderma } \text { fruiting bodies }(\%)\end{array}$ & -- & -- & 0 & 0 & 0 \\
\hline $\begin{array}{l}\text { Dead } M . \text { hexandra trees with } \\
\text { Ganoderma } \text { fruiting bodies }(\%)\end{array}$ & $35( \pm 35)$ & $42( \pm 17)$ & $27( \pm 5)$ & $4( \pm 4)$ & 0 \\
\hline $\begin{array}{l}\text { Live } M . \text { hexandra trees with } \\
\text { cankers }(\%)\end{array}$ & -- & -- & $86( \pm 9)$ & $83( \pm 5)$ & $82( \pm 9)$ \\
\hline
\end{tabular}

\section{Discussion}

Die-out of $M$. hexandra, the sole canopy dominant tree in TSD forests in BNP, was evident from this study and it may be imposing a severe threat to this wetland ecosystem. Around $68 \%$ of the individuals in the population of $M$. hexandra in BNP are either already dead or dying-back at present. TSD forests extend over a restricted area in Sri Lanka and BNP is the main example for such forests. Therefore, the death of $M$. hexandra trees in BNP is a serious threat leading to the loss of Sri Lankan biodiversity. Deflected natural regeneration and die-back of $M$. hexandra trees are the major causes for the die-out of the species. As a result, the population structure and spatial distribution of $M$. hexandra in BNP have been altered.

The density of $M$. hexandra in the study area varies over space and it is higher in relatively undisturbed TSD forests and DTSD forest patches than in the rest of the forest 
types. Both natural and anthropogenic disturbances and deflected natural regeneration may be the responsible reasons for this variation, in addition to the tree die-back. For instance, SJ plagioclimaxes contain a fewer number of mature individuals of the species (12 individuals $\mathrm{ha}^{-1}$ ) compared to the aforementioned two forest types. Among other reasons, this can be due to the shifting cultivation and selective logging implemented in this area in the past. In contrast, DSs and PDF stands contain a few or no individuals of the species and a direct cause for this may be the severe die-back of trees in this area in the recent past. Presence of dead trees and fallen logs of $M$. hexandra provide a good evidence for its dominance in such areas in the past. As a result, the density and the diameter distribution of $M$. hexandra in examined vegetation types have been altered and varied spatially. In addition, the deflected natural regeneration also contributes to the low density of $M$. hexandra in all the examined forest categories. Small individuals of which the $\mathrm{dbh}<2 \mathrm{~cm}$ were lacking in all the examined forest stands in BNP. This has been previously observed by Holms (1956) in other parts of the country. This poor natural regeneration may be due to seed and seedling predation or constraints associated with seed germination (Perera, 2007 ${ }^{\mathrm{b}}$ ). However, there are no anomalies in the production of fruits of this species within BNP and mass fruiting occurs in every 3-4 years when the climate favours towards fruit production (Gunarathne \& Perera, 2014).

The size-class distribution of $M$. hexandra population explained as a diameter-class distribution, in all studied forest stands is highly distorted. As Ogden (1970) explained, ageclass distribution which is used as a basic component of describing animal populations may not suit to describe the plant populations, as the age distribution in plants is less significant than size distribution. Therefore, in the current study, the density and size-class distributions of $M$. hexandra were examined to explain the impacts of tree die-back and deflected natural regeneration on the population structure of $M$. hexandra in BNP.

$M$. hexandra is reported to have a slow growth rate in terms of diameter increment (Holmes, 1956; Rutnum, 1959; Wijesinghe, 1959; de Rosayro, 1961; Fernando, 1962). However, it reaches a significant height $(7-8 \mathrm{~m})$ within a short period of time (within 8-10 years) as this light demanding canopy species has a habit of occupying the forest canopy as quickly as possible. Therefore, it is impossible to relate the tree height to the age but, the diameter of individuals of the species is somewhat comparable to their age than to their height. The largest individuals of $M$. hexandra in BNP had stems with $>50 \mathrm{~cm}$ dbh and $26 \%$ of trees of $M$. hexandra in BNP falls into this category. Therefore, by considering the diameter distribution of individuals, it can be assumed that many of the individuals in the population are over-mature.

The presence of over-mature cohorts in the population of $M$. hexandra has also been previously recorded from other parts of Sri Lanka and die-back of these is not an uncommon scene (de Rosayro, 1961). Over-mature trees are easily attacked by pests and pathogens (Goheen \& Hansen, 1993). Die-back symptoms have not been observed in seedlings and this may be due to the fact that these are somewhat resistant to tree die-back or they may die quickly without leaving any trace. The low dying-back records of trees in SJs may be due to the low density of the individuals of $M$. hexandra and subsequent low competition for resources, low density of invasive $P$. juliflora or due to the fact that diseased or unhealthy trees have already been removed in the past when the area was logged selectively or under shifting cultivation. However, in BNP, die-back does occur in mature individuals irrespective of their size and this implies that some other factors such as the presence of tree cankers or the heavy competition by invasive plants may influencing the death of $M$. hexandra trees in BNP in addition to the presence of old cohorts. 
Tree cankers appear as the most common visually observed disease symptoms in $M$. hexandra trees in BNP. Tree cankers were found on $>80 \%$ of live individuals in BNP and tend to be found everywhere irrespective of the vegetation category. Cankers were found on stems, base of stems or on branches, however, branch cankers tend to form more frequently. Monkeys inhabiting the park may damage twigs which cause to form wounds (Gunarathne \& Perera, 2014) and the canker forming microorganisms, especially fungi species such as Nectria sp. (Perera, 2007 ) may enter through such wounds. Cankers may weaken the plant and obstruct the water movements through the stem and therefore, shoots of plants with cankers may experience water scarcity especially during drought periods.

Invasion of the alien exotic $P$. juliflora may also be a reason for the die-out of $M$. hexandra from BNP. On the one hand, the allelopathic chemicals present in $P$. juliflora may suppress seedlings of $M$. hexandra, if any. It has been found that the root extracts of $P$. juliflora inhibited the radical growth of mung bean (Vigna radiata), black gram ( . mungo) and of some native forest plants (Perera et al., 2009). On the other hand, this fast growing invader may compete with mature $M$. hexandra trees for available resources, especially for water during drought periods (Gunarathne \& Perera, unpublished data). P. juliflora has been reported to have highly dispersed root systems (Pasiecznik et al., 2001) which may extend up to about $50 \mathrm{~m}$ in the soil (Raven et al., 2005). Mwangi \& Swallow (2005) have also reported that lands invaded by $P$. juliflora in Kenya suffered from water stress as they draw water efficiently from the ground water table. The lack of live $M$. hexandra trees and/or the presence of dead $M$. hexandra trees in DSs and PDF stands provide a strong evidence that the death of $M$. hexandra may be a result of the invasion by $P$. juliflora.

Opuntia dillenii is another invasive species which has spread over a significant area in BNP, but the current study reveals that it has no link to the tree die-back of $M$. hexandra. For instance, the density of $O$. dillenii was very high in SJ where the die-back incidences were low. Unlike $P$. juliflora, $O$. dillenii has a surface spreading root system and may not compete with $M$. hexandra for water during drought periods.

Ganoderma infection is not a causal factor for the tree death of $M$. hexandra in BNP though these fungal species have been reported to as attacking many economically important tropical plant species (Sankaran et al., 2005). In BNP, fruiting bodies of Ganoderma sp. were found only on dead trees but not on live trees and more commonly found in PDF stands and in adjacent DSs as these two forest types contained higher proportional abundance of dead trees than other forest types.

\section{Conclusion}

Tree die-back and poor natural regeneration are the direct causes for die-out of $M$. hexandra in BNP, which has significantly altered the population structure and the spatial heterogeneity of $M$. hexandra. The possible underlying reasons for this tree die-back include the invasion by $P$. juliflora and the subsequent increased competition for resources, presence of over-mature cohorts and the canker disease. However, Ganoderma infection and the invasion by $O$. dillenii may not be imposing a severe threat leading to the die-out of $M$. hexandra from BNP.

Currently, around $50 \%$ of the individuals in the relatively undisturbed TSD forests show die-back symptoms but it is possible to degrade further to form shrublands unless precautions are taken to halt tree die-back. As $P$. juliflora is progressively invading the land, $M$. hexandra trees in the remaining TSD forests are at a high risk of elimination and thereby the complete devastation of TSD forests in BNP. 


\section{Acknowledgements}

This study was funded by the Department of Wildlife Conservation (DWC), Sri Lanka (Grant No.: PAM \& WCP/DWC/Research/14). Authors wish to thank Mr. Sisira de Silva, Park Warden of BNP and the officers of DWC; Prof. N.K.B. Adikaram, Univerisy of Peradeniya; Dr. M. Nugaliyadda of Department of Agriculture, Nuwara Eliya; Prof. G. Senevirathna, Institute of Fundamental Studies, Kandy; Mr. Kosala Samarasinghe, Mr. Milinda Bandara, Mr. Lalith Wasantha and Ms. Wathsala for the support extended to conduct this study.

\section{References}

Auclair, A.N.D., 1993. Extreme climatic fluctuations as a cause of forest dieback in the Pacific rim. Water, Air and Soil Pollution, 66:207-229.

Bambaradeniya, C.N.B., Ekanayake, S.P., Fernando, R.H.S.S., Perera, W.P.N., Somaweera, R., 2002. A biodiversity status profile of Bundala National Park: A Ramsar Wetland in Sri Lanka. Occasional papers of IUCN Sri Lanka, No. 2: III.

Bauce, E., Allen, D.C., 1992. Role of Armillaria calvescens and Glycobius speciosus in a sugar maple decline. Canadian Journal of Forest Research, 22:549-552.

Blank, L.W. (1986). Deterioration, but some recovery. Nature, 319:529

Carey, A.C., Miller, E.A., Geballe, G.T., Wargo, P.M., Smith, W.H., Siccama, T.G., 1984. Armillaria mellea and decline of red spruce. Plant Disease, 68:794-795.

de Rosayro, R.A., 1961. The nature and the origin of secondary vegetational communities in Ceylon. Ceylon Forester, 5:23-46.

Fensham, R.J., Holman, J.E., 1999. Temporal and spatial patterns in drought-related tree dieback in Australian savanna. Journal of Applied Ecology, 36:1035-1050.

Fernando, D.F.S., 1962. Computation of girth increment rates for dry zone species - Satin, Ebony, Milla and Palu. Ceylon Forester, 5:191-192.

Gerrish, G., Mueller-Dombois, D., Bridges, K.W., 1988. Nutrient limitation and Metrosideros forest dieback in Hawaii. Journal of Ecology, 69:723-727.

Goheen, D., Hansen, E., 1993. Effects of pathogens and bark beetles on forests, in: Schowalter, T.D., Filip, G.M. (Eds.), Beetle- Pathogen Interactions in Conifer Forests. Academic Press, London, pp.175-196.

Gunarathne, R.M.U.K., Perera, G.A.D., 2014. Climatic factors responsible for triggering phenological events in Manilkara hexandra (Roxb.) Dubard., a canopy tree in tropical semi-deciduous forest of Sri Lanka. Tropical Ecology, 55:63-73.

Hibber, C.R., 1964. Identify and significance of certain organisms associated with sugar maple decline in New York woodlands. Phytopathology, 74:1389-1392.

Hinrichsen, D., 1986. Multiple pollutants and forest decline. Ambio, 15:258-265.

Hinrichsen, D., 1987. The forest decline enigma. Bio Science.. 37:452-546.

Holmes, C.H., 1956. The natural regeneration of the wet and dry evergreen forests of Ceylon. Ceylon Forester, 2:151-164.

Jacobi, J.D., 1983. Metrosideros dieback in Hawai'i: a comparison of adjacent dieback and non-dieback rain forest stands. New Zealand Journal of Ecology, 6:79-97.

Johnson, A. H., McLaughlin, S. B., 1986. The nature and timing of the deterioration of red spruce in the northern Appalachian Mountains. National Academy Science Report, Acid deposition: Long-term trends, National Academy Press, Washington DC., pp. 200-230. 
Kandler, O., Innes, J.L., 1995. Air pollution and forest decline in Central Europe. Environmental Pollution, 90:171-180.

Laurance, W.F., Williamson, B.G., Delamonica, P., Oliveira, A.A., Lovejoy, T.E., Gascon, C., Pohl, L., 2001. Effects of a strong drought on Amazonian forest fragments and edges. Journal of Tropical Ecology, 17:771-785.

Mader, D.L., Thompson, B.W., 1969. Foliar and soil nutrients in relation to sugar maple decline. Proceedings of Soil Science Society of America, 33:794-800.

McLaughlin, D., Gizyn, W., Mcllveen, W., Kinch, C., 1992. A quantitative tree crown rating system for deciduous forest health surveys: some results for Ontario, in: Manion, P.D., Lachance, D. (Eds.), Forest decline concepts. APS press, St. Paul, Minnesota, USA, pp.137-154.

Mueller-Dombois, D. (1980). The 'ohi'a dieback phenomenon in the Hawaiian rain forest, in: John Cairns, Jr. (Eds.), The recovery process in damaged ecosystems. Ann Arbor Science Publishers, Inc., pp.153-161.

Mueller-Dombois, D., 1986. Perspectives for an etiology of stand level dieback. Annual Review of Ecology and Systematics, 17:221-243.

Mueller-Dombois, D., 1990. Forest decline and soil nutritional problems in Pacific areas. Water, Air \& Soil Pollution, 54:195-207.

Mwangi, E., Swallow, B., 2005. Invasion of Prosopis juliflora and local livelihood: case study from the Lake Baringo area of Kenya. World Agroforestry Centre, Nairobi, Kenya.

Ogden, J., 1970. Plant population structure and productivity. Proceedings of the New Zealand Ecological Society, 17:1-9.

Papp, R.P., Kliejunas, J.T., Smith, R.S.Jr., Scharpf, R.F., 1979. Association of Plagithmysus bilineatus (Coleoptera: Cerambycidae) and Phytophthora cinnamomi with the decline of 'ōhi' a-lehua forests on the island of Hawaii. Forest Science, 25:187-196.

Pasiecznik, N.H., Felker, P., Harris, P.J.C., Harsh, L.N., Cruz, G., Tewari, J.C., Cadoret, K., Maldonado, L.J., 2001. The Prosopis juliflora-Prosopis pallida Complex. HDRA. Coventry, UK.

Perera, G.A.D., 2007a. Forest die-back in Bundala National Park. Protected Area Management and Wildlife Conservation Project, Department of Wildlife Conservation, Sri Lanka.

Perera, G.A.D., 2007b. Role of seeds in the regeneration of tropical semi-deciduous forests of Sri Lanka Abstracts of the Eco Summit 2007: challenges and opportunities for the $21^{\text {st }}$ century's ecology. Beijing, China.

Perera, G.A.D., 2012. Preset status of dry-zone flora in Sri Lanka, in: Weerakoon, D.K., Wijesundara, S. (Eds.), The national red list of Sri Lanka: Conservation status of the fauna and flora. Ministry of Environment, Colombo, Sri Lanka, pp.165-174.

Perera, G.A.D., Suranjith, G.A.N., Gunarathne, R.M.U.K., 2009. Allelopathic effect of Prosopis juliflora (Sw) DC and its impact on some Sri Lankan dry forest species, National Symposium on Invasive Alien Species, Negombo, Sri Lanka.

Pitelka, L.F., Raynal, D.J., 1989. Forest decline and acidic deposition. Ecology, 70:2-10.

Piyankarage, S.C., Mallawatantri, A.P., Matsuno, Y., Pathiratne, K.A.S., 2004. Human impacts and the status of water quality in the Bundala RAMSAR wetland lagoon system in southern Sri Lanka. Wetlands Ecology \& Management, 12:473-482.

Prinz, B., 1985. Prepared discussion. Environmental Science and Technology, 35:913-915.

Raven, P.H., Evert, R.F., Eichhorn, S.E., 2005. Biology of Plants, $7^{\text {th }}$ ed. Freeman. New York, USA.

Redmond, D.R., 1955. Studies in forest pathology XV. Rootlets, mycorrhiza, and soil temperatures in relation to birch dieback. Canadian Journal of Botany, 33:595-627. 
Rice, K.J., Matzner, S.L., Byer, W., Brown, J.R., 2004. Patterns of tree dieback in Queensland, Australia: the importance of drought stress and the role of resistance to cavitation. Oecologia, 139:190-198.

Rutnum, P.W., 1959. Growth of plants under the natural forest of dry zone. Ceylon Forester, 4:224.

Sankaran, K.V., Bridge, P.D., Gokulapalan, C., 2005. Ganoderma disease on perennial crops in India-an ovaeview. Mycopathologia, 159:143-152.

Schulze, E.D., 1989. Air pollution and forest decline in spruce (Picea abies) forest. Science, 244:776-783.

Smith, W.H. 1981. Air pollution and forests. Springer-Verlag, New York.

Suresh, H.S., Dattaraja, H.S., Sukumar, R., 2010. Relationship between annual rainfall and tree mortality in a tropical dry forest: Results of a 19 year study at Mudumalai, southern India. Forest Ecology \& Management, 259:762-769.

Turner, J., Lambert, M., 2005. Soil and nutrient processes related to eucalyptus forest dieback. Australian Forestry, 68:251-256.

Ulrich, B., 1983. Soil acidity and its relations to acid deposition, in: Ulrich, B., Pankrath. J. (eds.), Effects of accumulation of air pollutants in forest ecosystems. D. Reidel Publishing Company, Boston, Massachusetts, U.S.A., pp.127-146.

Ulrich, B., Mayer, R., Khanna, T.K., 1980. Chemical changes due to acid precipitation in a loess-derived soil in central Europe. Soil Science, 130:193-199.

Vogelmann, H.W., Badger, J.D., Bliss, M., Klein, R.M., 1985. Forest decline on Camels Hump, Vermont. Bulletin of the Torrey Botanical Club, 112:274-287.

Vries, W.D., Kalp, J.M., Erisman, J.W., 2000. Effects of environmental stress on forest crown condition in Europe. Part I: Hypotheses and approach to the study. Water, Air and Soil pollution, 119:317-333.

Whitmore, T. C., Sayer, J.A., 1992. Tropical deforestation and species extinction. Chapman and Hall, London.

Wijesinghe, L.C.A., 1959. A study of girth increment of Manilkara hexandra Dubard (Palu). Ceylon Forester, 4:219-224.

Wood, A., Stedman-Edwards, P., Mang, J., 2000. The root causes of biodiversity loss. World Wildlife Fund and Earthscan Publications Ltd., U.K. 